\section{South African university politics still hanging in the balance}

\section{London}

A full bench of the Cape Supreme Court has ruled that the conditions imposed on the universities of Cape Town and the Western Cape (UCT and UWC) are invalid and has ordered the ministers of Education and Culture in the Houses of Assembly and Representatives to pay the costs of the application. The conditions, promulgated on 16 October last year by the South African government, provide for cutting the state subsidy to universities refusing to report incidents of political activity on their campusses (see Nature 329, 192; 330, 4; and 331, 104, 1987).

The bench, comprising Mr Justice Nel, $\mathrm{Mr}$ Justice Conradie and $\mathrm{Mr}$ Justice Howie, made this ruling on 11 February; full judgement will be furnished at a later date. In a parallel application, counsel for UCT and UWC asked the ministers to show why the decision to impose the conditions should not be reviewed or set aside. Alternatively, they applied for an order declaring the conditions invalid and without force and effect. Evidence pro-

tended that any substantial reduction in their annual subsidy would gravely prejudice the universities' educational functions, and render them unable to fulfill their purpose and obligations under their founding statues and other relevant legislation. They submitted that the conditions encroached upon and were in conflict with the autonomy and functions conferred on the university by parliament.

The outcome of a similar application by Natal University is currently being awaited, but the Cape Supreme Court's ruling is not binding in the province of Natal. Depending on the outcome of the Natal application, the government may decide to take the case to the Appellate Division of the Supreme Court in Bloemfontein, but in the interim they are powerless to impose a subsidary cut on either UCT or UWC without changing the law itself. While their huge parliamentary majority would allow them to do this, the Cape Supreme Court ruling provides the ideal opportunity for the government to back down, if it is inclined to do so.

Michael Cherry duced in court by the universities con-

\section{Royalties to be paid on animal patents}

\section{Washington}

FARMERS who breed genetically altered animals covered under US patents will have to pay royalty fees, according to a letter from the US Patent and Trademark Office (PTO) released two weeks ago. The letter, written by patent office commissioner Donald J. Quigg to the chairman of the Senate subcommittee on patents, copyrights and trademarks last autumn, was released to the media by the Foundation on Economic Trends, headed by Jeremy Rifkin. In the letter, Quigg makes it clear that according to the current interpretation of patent statutes, "unauthorized acts of reproduction ... . [of patented animals] would seem to be an infringement".

The effect of animal patenting on farmers has been debated hotly since the PTO announced last spring of that it would consider applications for such patents (see Nature 326, 729; 1987). Major farming organizations have protested against PTO's action, and legislation was introduced by Senator Mark Hatfield (Republican, Oregon) in the last Congress to impose a two-year moratorium on animal patenting so that the economic and ethical implications could be resolved. Although the legislation was not passed by Congress, Hatfield plans to introduce it again this year. The congressional Officers of Technology Assessment is also preparing a study of the potential effects of the patent- ing of animals, due for release this summer.

The PTO is currently reviewing 20-22 applications for patents on animals, and provided that the applications meet the

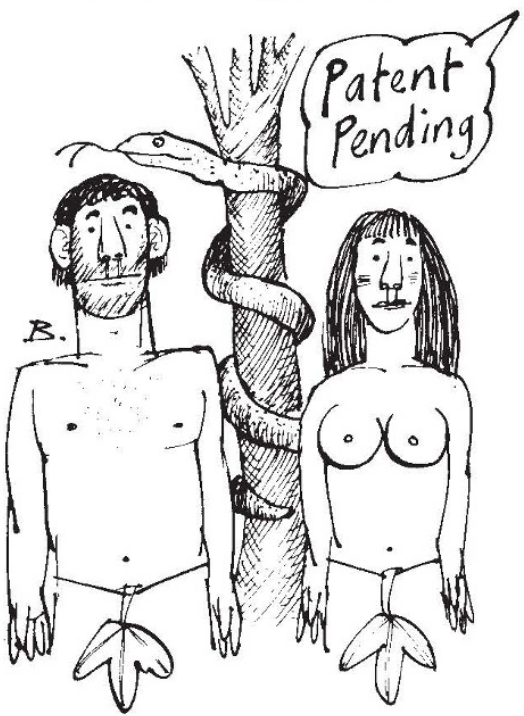

usual criteria for patentability, the first animal patent could be granted as early as this summer. But the ability to patent animals will not ensure market success. If genetically altered animals are not competitive in price or better than those produced by traditional methods, farmers may still choose to buy animals that will not be subject to royalty payments. Carol Ezzell

\section{Rehabilitator for Vavilov comes to light}

\section{London}

A Member of the Soviet Academy of Sciences, Dr Artem Takhtadzhyan, last week publicly acknowledged his debt to the emigré writer Mark Popovsy, thus signalling a further relaxation of the rules of public discussion in the Soviet Union.

This development has come about in Literaturnaya Gazeta, in which there has been a vigorous correspondence since the centenary of the birth of the geneticist Nikolai Vavilov on 25 November last year. Popovsky, who emigrated from the Soviet Union in 1977, is an authority on Vavilov's life and the circumstances of his death (in prison) as one of the victims of the Lysenko period, but apart from one mention in a scientific bibliography last year, this is the first time Popovsky's work on Vavilov has been acknowledged.

Vavilov was formally rehabilitated in 1955 , but open discussion of the purge of geneticists was permitted only for a brief period at the end of the 1960 s. Popovsky then published an account of the campaign against Vavilov in the 1930s, evoking the atmosphere of fear preceding Vavilov's arrest in 1940, but only in the journal Prostor, published in Alma-Ata.

After leaving the Soviet Union, Popovsky pursued his work on Vavilov, gaining access to much archival material, including the secret police file on Vavilov housed in the State Prosecutor's Office; his findings were published in The Vavilov Affair (Archon Books) only in 1984.

In the Soviet Union, preparations for the Vavilov centenary began in 1985 , when two films were commissioned. In November last year, Ogonyok published an article by the script-writer of one of the two films that stressed the scale of the persecution of the 1930 s, while Literaturnaya Gazeta published a long article by Academician Takhtadzhyan which drew heavily on Popovsky's material, noting Vavilov's ambivalence towards Lysenko and that Vavilov, although at first denying the charges of sabotage and espionage against him, eventually "recanted", not necessarily because he was torturted.

Since last November, Soviet readers have written to ask how reliable these revelations are, but those elsewhere have noted with regret the use of Poposky's material without acknowledgement. Takhtadzhyan has now answered both sets of critics by quoting the cooperation of the official Vavilov commission and saying that "the basic material on Vavilov's work and his tragic end were obtained due to the energetic activities of the writer M.A. Popovsky..." Vera Rich 